\title{
Identification of Source Water Mixing in the Fish Slough Spring Complex, Mono County, California, USA
}

\author{
Andy Zdon ${ }^{1, *}$, Keith Rainville ${ }^{2}$, Nicholas Buckmaster ${ }^{3}$, Steve Parmenter ${ }^{3}$ and Adam H. Love 4 \\ 1 Partner Engineering and Science, Inc., 1761 E. Garry Avenue, Santa Ana, CA 92705, USA \\ 2 Inyo County Water Department, 135 S. Jackson Street, Independence, CA 89518, USA; \\ krainville@inyocounty.us \\ 3 California Department of Fish and Wildlife, Inland Deserts Region, 787 North Main Street, Suite 220, Bishop, \\ CA 93514, USA; Nick.Buckmaster@wildlife.ca.gov (N.B.); Steve.Parmenter@wildlife.ca.gov (S.P.) \\ 4 Roux Associates, Inc., 555 12th Street, Suite 250, Oakland, CA 95607, USA; ALove@rouxinc.com \\ * Correspondence: AZdon@partneresi.com
}

Received: 27 February 2019; Accepted: 15 March 2019; Published: 20 March 2019

\begin{abstract}
While the desert ecosystem is highly dependent on the water resources that sustain it, the Fish Slough spring complex is an arid, spring-dependent wetland undergoing a multidecadal decline in spring outflow. This evaluation updates the source water forensics of the Fish Slough Spring complex, a substantial spring complex in the northern Owens Valley of the Basin and Range geomorphic provinces, in order to better understand the nature of the spring flow decline. The source of spring flow at Fish Slough was evaluated through an integration of the established geologic setting with measured groundwater elevations, and water quality and isotope chemistry compiled from both previously published sources and collection of new samples. While previous efforts to source the Fish Slough springs only considered potential source areas within the local geography, this evaluation considered a larger geographic extent for potential source areas to the spring water. The results infer that Fish Slough springs are sourced from multiple source water areas in hydraulic communication: a basin fill aquifer and warm, sodic spring systems with distinctive chemical signatures. Mixing from these sources occurs along two hypothesized flow paths, one from the northeast through the Tri-Valley area and one from the north and northwest through the Volcanic Tablelands. Northeast Spring has the strongest signature for Tri-Valley area waters, whereas the remaining Fish Slough Springs are comprised of a mixture of both flow paths. These conclusions have important implications for water management activities that have the potential to impact the desert ecosystem supported by these springs.
\end{abstract}

Keywords: water resources; Owens Valley; springs; groundwater; recharge; forensics; isotopes

\section{Introduction}

The Fish Slough springs are within the Fish Slough Area of Critical Environmental Concern, north of Bishop, California in southern Mono County (Figure 1). These springs are adjacent to areas with significant human population, agriculture, and water exporting activities. Historically, periodic investigations into the local source of the water discharged at Fish Slough have been conducted due to declining spring flows over multiple decades, but have failed to provide answers as to the cause for the spring flow decline. The need for a more regional approach to conducting the analysis of source water to the area was identified. As such, the goal of this project is to improve the understanding of the water source(s) that sustains the springs at Fish Slough, and the desert ecosystem that is dependent on that 
resource. Fish Slough supports many important species such as the federally- and state-endangered Owens Pupfish and the federally-threatened plant, Fish Slough milk-vetch.

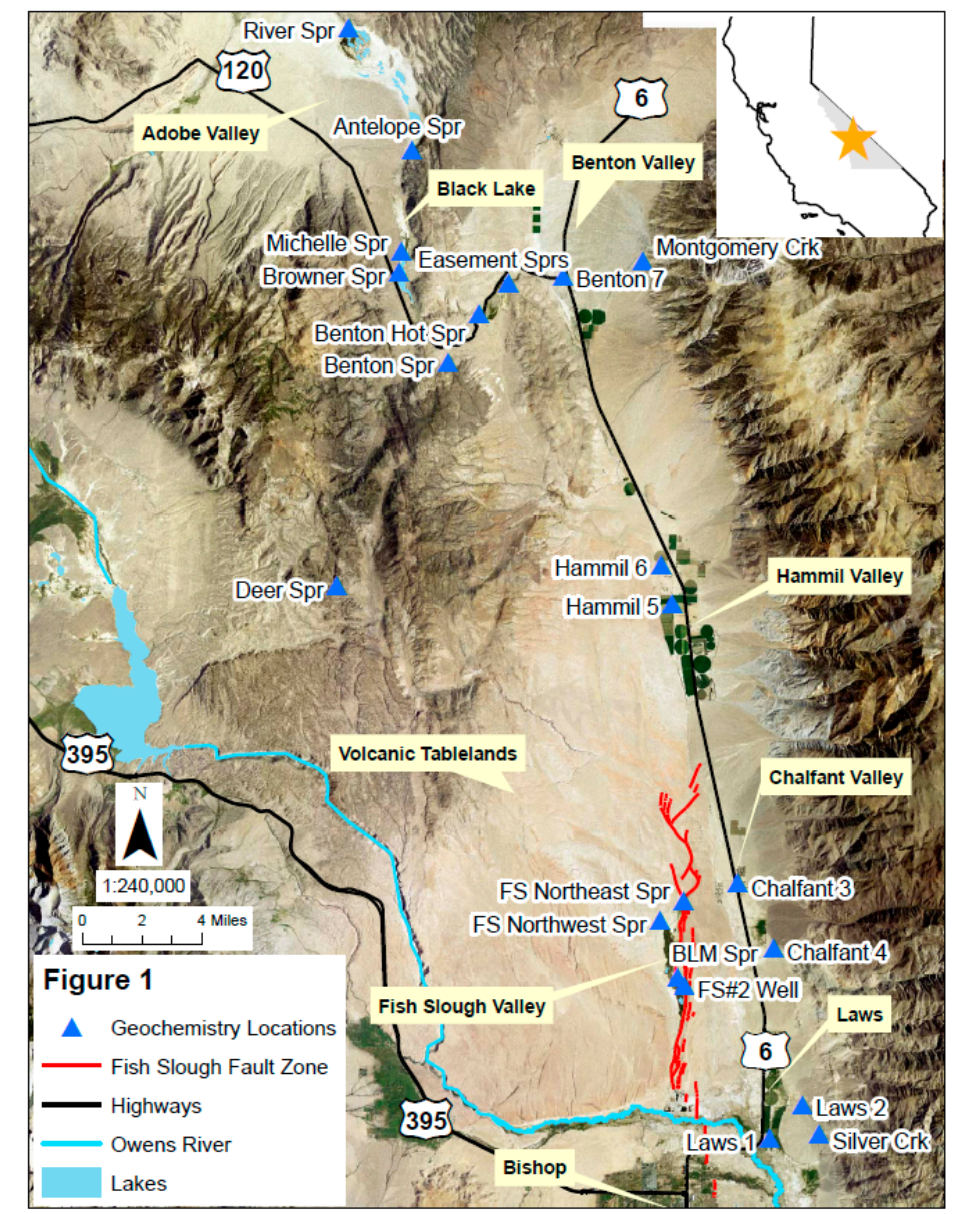

Figure 1. Location of Fish Slough Valley, which contains the Fish Slough Area of Critical Environmental Concern and the Spring locations (Spr) within and nearby Fish Slough Valley.

The Fish Slough spring complex consists of multiple springs systems with numerous individual vents varying in size, from small seeps up to fourth-order springs (discharge of $380 \mathrm{~L}$ to $1700 \mathrm{~L}$ per minute), based on the most recent flow measurements and classification [1]. Among the key springs in Fish Slough are BLM Spring, Northeast Spring, and Northwest Spring (Figure 1). The combined spring discharge drains into a perennial stream and flows south through the wetland to the Owens River. A Parshall flume (Gauge 3216) located approximately 3 miles downstream from BLM Springs meters the composite flow from Fish Slough. Annual variations in gauged flow arise from precipitation events (primarily winter) and summer evapotranspiration in the wetland. However, a long-term decline in flow is evidenced outside of these annual variations, potentially related to agricultural pumping and/or pumping by Los Angeles Department of Water \& Power.

The initial goal of this investigation was to address the question "what is the source of water discharging from Fish Slough springs?" This investigation addresses these issues using multiple aqueous geochemical indicators within the context of the regional geology. Either purely geological or purely geochemical evaluations are frequently insufficient to address water sourcing questions. However, understanding specific flow paths, including discrete geologic structures or earth materials, that result in water preferentially moving from the source area to the discharge point is beyond the scope of this study. Conclusions regarding flow paths are general and based on the results from previous regional geologic studies; conclusions regarding geochemical signatures are based on 
laboratory analysis of water samples collected from springs and other surface waterbodies in the area as part of this investigation in combination with existing data from regional groundwater studies.

\section{Previous Studies}

Hydrologic investigations in the California desert have generally focused on assessment for a specific need or objective. In the Fish Slough area, there have been three phases of investigation:

1. An early reconnaissance phase during the early to mid-decades of the twentieth century, conducted to understand the regional geology, along with a focused evaluation of the Fish Slough area as a potential reservoir site.

2. Investigations related to development of a water resource available for export out of the Owens Valley groundwater basin that were based on historical literature review and hydrologic modeling, with no Fish Slough-specific field work.

3. Efforts in recent decades to comprehensively document and understand Fish Slough and causes for the declining flow of the spring.

The early reconnaissance phase investigations in this area were conducted by Knopf and Kirk [2], Bateman [3], and the California Department of Water Resources [4]. In 1918, Knopf and Kirk [2] described the presence of Fish Slough springs and present geologic maps that report the useable riparian area of the Fish Slough spring prior to water development (e.g., pumping by the City of Los Angeles and agricultural pumping in the Tri-Valley area). In the 1960s, Bateman [3] described the structural geology of the region, including Fish Slough, and the California Department of Water Resources report [4] presented the results of a feasibility investigation for Fish Slough as a dam and reservoir site.

In 1991, the first report to provide a spring-specific hydrogeological and ecological characterization of Fish Slough was presented in "Biotic Inventory and Ecosystem Characterization for Fish Slough" [5]. That report provided a comprehensive overview of land and water use, hydrogeology, biological resources, and management opportunities associated with the Fish Slough spring system.

In 1998, Danskin [6] prepared an Owens Valley-wide evaluation of the regional conceptual hydrologic model and specific water management alternatives, which included the Fish Slough spring system at the margin of the study area. This report (and its earlier companion Hollett, Danskin et al. [7]) provided the regional hydrogeologic context that was the basis for the current investigation.

In 2002, Chapman [8] conducted reconnaissance-level sampling for stable isotopes in the Fish Slough area on behalf of the BLM. In 2006, the U.S. Geological Survey (USGS) conducted groundwater sampling and analysis in the region as part of the Groundwater Ambient Monitoring and Assessment (GAMA) program. Groundwater from the Eastern Sierra was sampled in the vicinity of Laws, Chalfant Valley, Hammil Valley, and Benton/Benton Hot Springs, among others, and analyzed for a comprehensive suite of groundwater constituents and characteristics. The data from that effort is publicly available on the National Water Information Service (NWIS) website [9].

In 2010, the USGS released an administrative report [10] summarizing the geologic and hydrologic information that had been developed for Fish Slough up to that time and evaluated the results of geochemical sampling of the springs and nearby groundwater (primarily in the Chalfant Valley and Laws area to the east). This report provided an initial assessment of the general hydrogeologic conditions and was also a basis for the current investigation. In 2014, CDFW [11] released a vegetation map and associated classification of Fish Slough based on field data collected during 2011 through to 2013. The purpose of that work was to assist in the management and long-term vegetation monitoring of the Fish Slough Ecological Reserve and ACEC [11].

During 2015 and 2016, Andy Zdon \& Associates [12] conducted a spring survey on behalf of the BLM, The Nature Conservancy, and Transition Habitat Conservancy for BLM's Needles, and Barstow and Ridgecrest Field Offices. The field methods used for those surveys are the same as those used for the current investigation and therefore provide regional continuity and comparable data $[13,14]$. 


\section{Materials and Methods}

For this analysis, water samples collected from the springs that make up the Fish Slough springs complex and other springs in the region (Figure 1) were analyzed for general minerals, trace metals analysis (conducted by Alpha Analytical, Inc., in Sacramento, California), and stable isotope and tritium analyses (conducted by Isotech Analytical Laboratories, Inc., in Champaign, Illinois).

Samples for general minerals analysis were collected in 1-L HDPE sample bottles provided by the laboratory (no preservative was used). Samples for trace metals were collected in 250-mL HDPE sample bottles provided by the laboratory (nitric acid preservative was used). Samples were maintained on ice and shipped to the laboratory in proper holding times (with the exception for nitrate).

Samples for oxygen $\left(\delta^{18} \mathrm{O}\right)$, deuterium $(\delta \mathrm{D})$, and tritium $(3 \mathrm{H})$ were collected in 1-L HDPE sample bottles provided by the laboratory. Samples were shipped to Isotech Laboratories in Champaign, Illinois where the ${ }^{18} \mathrm{O} /{ }^{16} \mathrm{O}$ and $\mathrm{D} / \mathrm{H}$ ratios were measured as a gas using standardized mass spectrometry methods. ${ }^{3} \mathrm{H}$ analysis was conducted using the tritium enhanced enrichment (TEE) method to obtain lower reporting limits. As is standard, the $\delta^{18} \mathrm{O}$ and $\delta \mathrm{D}$ results are reported as a normalization to Standard Mean Ocean Water (SMOW) and expressed in $\delta$ ("del") notation.

During site visits, field water quality parameters of temperature, $\mathrm{pH}$, electrical conductivity, and dissolved oxygen were measured at the sources of the springs. Field instruments were checked for calibration daily, if not at higher frequencies.

The analytical results from these samples were combined with previously collected data from wells and springs to evaluate water sourcing in the region (Table 1 and Table S1). The Pan American Center for Earth and Environmental Studies (PACES) compiled USGS terrain-corrected, complete Bouguer anomaly reduced to background density of 267 gravity data from gravimeter stations across the United States. Hildenbrand [15] describes the data gathering efforts. PACES regional geospatial service center's online "Gravity and Magnetic extract utility" at http:/ / research.utep.edu/default. aspx?tabid=37229 was used to download Eastern Sierra data. The gravity anomaly contour map (Figure 2) was created using the ArcMap Geostatistical Analyst Empirical Bayesian Kriging. These more recent data largely agree with and confirm the presence and location of the bedrock block identified by Pakiser et al. [16] and noted by Bateman [3] and Hollet et al. [7]. 
Table 1. Sampling information, measured field water quality parameters, and measured isotope composition of water from identified locations in Figure 1. Note: Coordinates in WGS1984; pH was variable with discharge; NA indicates not analyzed; NM indicates not measured; ND indicates non-detect.

\begin{tabular}{|c|c|c|c|c|c|c|c|c|c|c|c|c|c|}
\hline Feature & Date & Owner & $\begin{array}{l}\text { Latitude } \\
\text { (1) }\end{array}$ & $\begin{array}{l}\text { Longitude } \\
\text { (1) }\end{array}$ & $\begin{array}{c}\text { Elev } \\
\text { (ft msl) }\end{array}$ & $\mathrm{pH}$ & $\begin{array}{l}\text { Temperature } \\
(\operatorname{deg} C)\end{array}$ & $\begin{array}{l}\text { Conductivity } \\
(f \hat{\mathrm{E} S})\end{array}$ & $\begin{array}{c}\text { TDS } \\
\text { (ppm) }\end{array}$ & $\begin{array}{l}\text { Dis. Oxygen } \\
\text { (mg/L) }\end{array}$ & $\mathrm{dD}$ & d18O & 3H (NTU) \\
\hline \multicolumn{14}{|l|}{ Fish Slough Area } \\
\hline BLM Spring & $3 / 15 / 2017$ & BLM & 37.48044 & -118.40324 & 4195 & 7.66 & 20 & 436 & 219 & 3.06 & -126.7 & -16.35 & $\mathrm{ND}<0.6(5)$ \\
\hline BLM Spring (Upper Vent) & $3 / 15 / 2017$ & BLM & 37.48059 & -118.40329 & 4195 & $7.80(2)$ & 20.9 & 507 & 252 & 4.06 & -126.5 & -16.37 & $\mathrm{ND}<0.6$ \\
\hline BLM Spring (Linear Vent) & $3 / 15 / 2017$ & BLM & 37.48031 & -118.40260 & 4195 & 8.03 & 22.4 & 509 & 255 & 3.5 & -124.7 & -16.27 & NA (3) \\
\hline FS Northeast Spring (NE Spring) & $6 / 10 / 2017$ & LADWP & 37.51793 & -118.40016 & 4217 & 7.89 & 21.6 & 384 & 191 & 0.93 & -122.8 & -16.25 & $\begin{array}{c}0.76 \\
(+-0.25)\end{array}$ \\
\hline FS Northwest Spring (NW Spring) & $6 / 10 / 2017$ & LADWP & 37.50801 & -118.41431 & 4203 & 7.89 & 20.3 & 356 & 178 & 2.46 & -124.9 & -16.20 & NA \\
\hline Fish Slough Well \#2 & $3 / 15 / 2017$ & LADWP & 37.47654 & -118.39893 & 4186 & 7.79 & 11.7 & 535 & 266 & 2.54 & -121.7 & -15.97 & $<0.71$ \\
\hline \multicolumn{14}{|l|}{ Adobe Valley/Benton Range } \\
\hline River Spring & $3 / 14 / 2017$ & BLM & 37.93850 & -118.61340 & 6496 & 8.14 & 16.7 & 195 & 98 & 3.67 & -132.5 & -17.34 & $<0.6$ \\
\hline River Spring (Dock Vent) & $3 / 16 / 2017$ & BLM & 37.93850 & -118.61340 & 6496 & 8.23 & 16.9 & 190 & 95 & 2.68 & -132.5 & -17.37 & NA \\
\hline Antelope Spring & $3 / 14 / 2017$ & BLM & 37.87929 & -118.57342 & 6494 & 8.09 & 15 & 238 & 122 & 3.03 & -132.0 & -17.28 & $<0.65$ \\
\hline Deer Spring & $4 / 20 / 2017$ & INF & 37.66747 & -118.61458 & 7290 & 7.07 & 9.2 & 222 & 111 & 3.46 & -119.9 & -15.64 & 2.27 \\
\hline "Michelle Spring" & $4 / 20 / 2017$ & ESLT & 37.83012 & -118.57882 & 6425 & 7.68 & 12.2 & 186 & 94 & 1.72 & -132.7 & -17.36 & NA \\
\hline "Browner Spring" & $4 / 20 / 2017$ & ESLT & 37.82000 & -118.58013 & 6430 & 7.64 & 25 & 470 & 226 & 1.31 & -115.0 & -14.57 & NA \\
\hline Unnamed (UN) \#1 (W of Black Lake) & $3 / 14 / 2017$ & BLM & 37.80527 & -118.60192 & 7171 & NM & NM (4) & NM & NM & NM & NM & NM & NA \\
\hline Unnamed (UN) \#3 (SW of Benton HS) & $3 / 16 / 2017$ & BLM & 37.77710 & -118.54913 & 6209 & 7.02 & 8.8 & 89 & 45 & 5.25 & -117.9 & -15.30 & NA \\
\hline Easement South Spring & $4 / 21 / 2017$ & Private & 37.81525 & -118.51291 & 5550 & 7.44 & 17.9 & 427 & 213 & 3.09 & -131.8 & -16.68 & $<0.52$ \\
\hline Easement North Spring & $4 / 21 / 2017$ & Private & 37.81580 & -118.51267 & 5545 & 7.22 & 16.9 & 469 & 235 & 1.43 & -131.1 & -16.57 & $\mathrm{NA}$ \\
\hline Benton Hot Springs & 1977 & Private & \multicolumn{3}{|c|}{ Coordinates not provided in report } & 9.32 & 56.5 & NM & NM & NM & -135.5 & -17.46 & NA \\
\hline \multicolumn{14}{|l|}{ White Mountain Creeks } \\
\hline Montgomery Creek-Lower & $3 / 14 / 2017$ & BLM & 37.81729 & -118.44451 & 5875 & 7.92 & 10.4 & 166 & 83 & 7.42 & -116.8 & -15.62 & NA \\
\hline Montgomery Creek-Upper & $3 / 14 / 2017$ & BLM & 37.82767 & -118.43083 & 6441 & 7.78 & 8.1 & 164 & 82 & 10.31 & -117.5 & -15.70 & NA \\
\hline Silver Creek-Lower & $3 / 14 / 2017$ & BLM & 37.41891 & -118.32289 & 4200 & 7.96 & 8.1 & 412 & 205 & 13.3 & -125.9 & -16.52 & NA \\
\hline Silver Creek-Upper & $3 / 14 / 2017$ & BLM & 37.40554 & -118.31546 & 4416 & 6.81 & 10.3 & 75 & 37 & 13.28 & -126.0 & -16.56 & NA \\
\hline \multicolumn{14}{|l|}{ Tri-Valley GAMA Wells } \\
\hline “GAMA\#1”-Laws 1 & $10 / 5 / 2006$ & & 37.40308 & -118.34547 & 4122 & 7.5 & 17.5 & $\begin{array}{c}816 \\
\text { (sp.cond) }\end{array}$ & NM & 5.5 & -120 & -15.82 & 0.59 \\
\hline “GAMA\#2”-Laws 2 & $8 / 23 / 1978$ & & 37.41972 & -118.32583 & 4185 & NM & 34 & 430 & NM & NM & -124 & -16.46 & 1.09 \\
\hline "GAMA\#3"-Chalfant 3 & $10 / 5 / 2006$ & & 37.52683 & -118.36722 & 4256 & 7.7 & 17.5 & 364 & NM & 7 & -121 & -16.07 & 0.09 \\
\hline "GAMA\#4"-Chalfant 4 & $9 / 11 / 2006$ & & 37.49536 & -118.34481 & 4265 & NM & NM & NM & NM & NM & -126 & -16.86 & 0.5 \\
\hline "GAMA\#5"-Hammil 5 & $10 / 2 / 2006$ & & 37.66175 & -118.40953 & 4550 & 7.9 & 15 & 275 & NM & 8.4 & -122 & -16.39 & 0.59 \\
\hline "GAMA\#6"-Hammil 6 & $10 / 2 / 2006$ & & 37.68067 & -118.41683 & 4590 & 7.8 & 17 & 404 & NM & NM & -122 & -16.03 & 0.5 \\
\hline “GAMA\#7"-Benton 7 & $10 / 5 / 2006$ & & 37.81961 & -118.47953 & 5380 & 7.4 & 15 & 372 & NM & 5.2 & -121 & -16.10 & 0.09 \\
\hline
\end{tabular}




\section{Results}

The results of this analysis integrate the geologic framework, hydrogeology, and geochemical and isotopic composition of the waters sampled.

\subsection{Geologic Framework}

The Fish Slough spring system is located within the southeastern Volcanic Tablelands in northern Owens Valley, CA. The Owens Valley is the far-western portion of the Basin and Range geomorphic province [17], bounded by the Sierra Nevada mountains to the west and the White Mountains to the east, primarily filled with recent alluvium, and exhibiting transtensive deformation. The rocks comprising the Volcanic Tablelands are the Bishop Tuff, a rhyolitic pyroclastic flow resulting from the catastrophic eruption of the Long Valley Caldera to the northwest approximately 760,000 years ago. The Bishop tuff consists of numerous ash deposits approximately 400-600 feet thick and sloping from northwest to southeast. Additionally, pre- and postcaldera eruption volcanism in the area (e.g., at Glass Mountain and Adobe Valley) have deposited recent volcanics.

The Fish Slough springs are located at elevations of approximately 4200 feet above mean sea level depending on the specific spring. Average annual temperatures at the closest nearby meteorological stations with long-term records are $13.4^{\circ} \mathrm{C}\left(56.1^{\circ} \mathrm{F}\right.$ based on a record from 1895 to 2016) at Bishop Airport (south 9 miles, elevation 4140 feet above mean sea level), with other stations in the area (such as at Benton and Fish Slough) having incomplete and substantially shorter records [18].

Across the Owens Valley, there is a north-northwest fault trend with a secondary northeast fault trend also present (likely the result of relay faults between the Fish Slough Fault, the White Mountain Fault, and other subsidiary faults, all parallel to the prevailing structural regime (Figure 2). As described by Jayko and Fatooh [10] and Bateman [3], the east side of Fish Slough is a half-graben, bounded by the Fish Slough fault zone. Fish Slough is a complex fault zone comprised of a series of normal faults with some oblique movement (right lateral) linked by stepovers and relay ramps. Both BLM and Northeast Springs discharge from this fault zone, and it is reasonable to expect that these seemingly discontinuous faults (as observed at the surface) are linked at depth providing a fracture-dominated flow path through the Bishop Tuff for regional flow to the springs. There is indication in the Bishop Tuff that the Fish Slough Fault system extends northwards in a series of en echelon faults into the southern portion of Hammil Valley, capturing the primary ephemeral wash and deflecting it to the southwest towards Fish Slough into Chidago Canyon. Further indications of this fault system may have been obscured by the White Mountain bajada.

The geologic units influencing groundwater chemistry are primarily silicic in content but have diverse lithologies. In the White Mountains, Precambrian- to Mesozoic-aged rock types range from calcareous sediments to metasediments and younger granitic rocks. In the Volcanic Tablelands, the adjoining Benton Range, and the Adobe Valley area, the principal rock types present are tertiary to quaternary volcanic rocks consisting of rhyolite, andesite, basalt, and other pyroclastic rocks. Mesozoic-aged granites and granodiorites are also present, such as at Blind Spring Hill near Benton Hot Springs to the north and Casa Diablo Mountain to the northwest, along with older Paleozoic metasediments. 


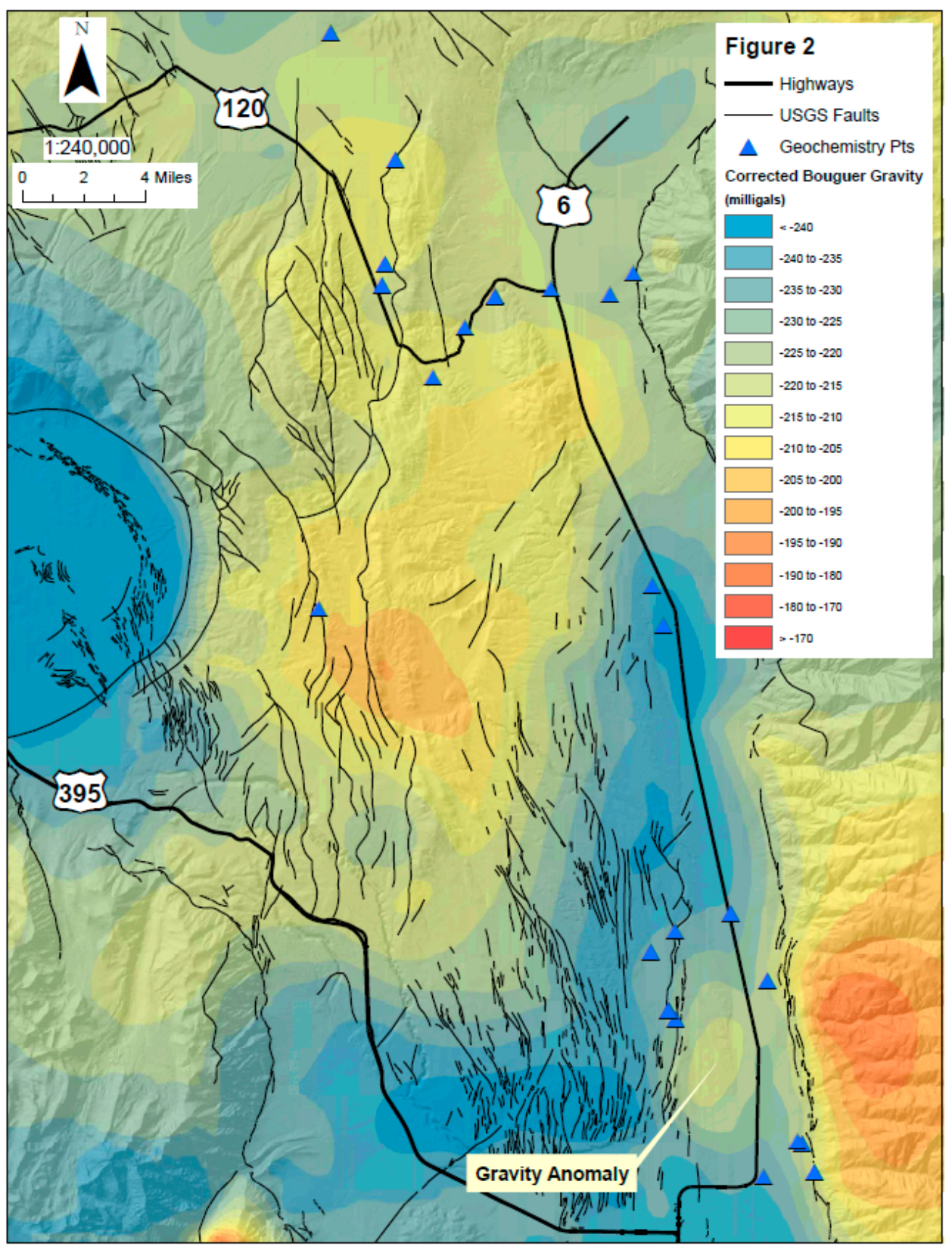

Figure 2. Structural features within and nearby the Fish Slough valley.

\subsection{Hydrogeology}

The principal surface waterbodies in the Fish Slough area are the springs in the region (Figures 1 and 2), and the Owens River to the south. The primary source of recharge is from precipitation and periodic snowmelt runoff from the higher surrounding mountains which percolates into fractured rock surfaces or recharges basin alluvium. In the surrounding mountains (e.g., the Benton Range) most of the springs are "local" or "perched" springs (e.g., Deer Spring) located at higher elevations in the mountains. These local springs are assumed to be sourced from precipitation in their respective watersheds that percolates into the ground, only to reach bedrock or minor fault restrictions which force water to the surface. These springs are typically in wash bottoms or may form small, intermittent seeps on hillsides. In contrast, larger springs such as at Fish Slough and River Spring are observed in 
the valley floors of the Benton Range/Volcanic Tablelands and in the Benton Hot Springs area along prominent geologic structures or geologic contacts.

In general, the direction of groundwater movement in this region typically parallels the slope of the ground surface, from points of recharge in the higher elevations to points of discharge, such as springs, wells, or other surface waters. To the north, in Adobe Valley, groundwater will infiltrate alluvium or volcanic rocks and discharge in the vicinity of Black Lake. From the Benton Range, groundwater will move from the east slope of the Benton Range toward the town of Benton and the Tri-Valley area. Along the western front of the White Mountains, groundwater will flow from Benton Valley south towards Hammil and Chalfant valleys.

South of Chalfant, a subsurface bedrock high exists, indicated by geophysical data (gravimetric) (Figure 2) and well logs on file with the California Department of Water Resources. Hollett et al. [7] noted that "the northern extension of the valley graben under Chalfant, Hammil and Benton Valleys is partly isolated from the deepest part of the Bishop Basin by a bedrock slump block ... that partially obstructs the south end of the Chalfant Valley.... The protrusion of the buried slump block at the south end of Chalfant Valley, conjunctive with the overlying fan, probably deflects deep ground water-flowing south along the Chalfant, Hammil, and Benton Valleys to the Bishop Basin-farther west beneath the southeastern part of the Volcanic Tableland near Fish Slough. This is west of where underflow would be expected on the basis of present topography."

The Volcanic Tableland in the vicinity of Fish Slough is an east dipping surface that rises to elevations above 7000 feet in the vicinity of Casa Diablo Mountain. An ephemeral wash in Chidago Canyon routes surface water through the eastern portion of the Tablelands and groundwater recharge from this vicinity likely flows southeast toward Fish Slough.

In Fish Slough, water moves southward from the springs and seeps toward the Owens River. Since the Fish Slough spring system rises along a structural trend within the Volcanic Tableland, each spring consists of multiple spring vents with waters discharging at multiple locations. The most upgradient springs are Northeast Spring and Northwest Spring. South of these springs lies BLM Spring, with its multiple vents, including one feature that appears to rise along a planar fracture and is visible as a linear expression of organic material along the channel bottom. Surface flow of spring discharge is generally toward the south through a north-trending wetland where flow is captured in a stream that heads southward toward the Owens River. Flow is measured at several locations (Figure 3). Overall, the most representative flow measurement for the Fish Slough spring system is at Gauge \#3216 ("Fish Slough at LA Station") with spring discharge being equal to the flow measurement, plus unmeasured evapotranspiration from the springs above that location minus recent precipitation. Flow has been measured at this location since 1966 [19]. As shown on the hydrograph for Gauge \#3216 (Figure 4a), the 1980s began a decline in flow through approximately 2010. Since that time, flow may have stabilized at a lower volume.

Northeast Spring is measured at a Parshall flume, Gauge \#3208 ("Fish Slough Below Pond 1"). As shown on the hydrograph (Figure 4b), consistent flow measurement at this location has occurred from 1990 through present [19]. As can be seen, flow at Northeast Spring declines steadily from 1990 with no indication that the spring flow has reached a stable volume. Flow data from gauges at Northwest Spring and BLM Spring are not presented here as field staff have noted [20] likely errors and inconsistencies caused by device failure or maintenance issues at those locations. 


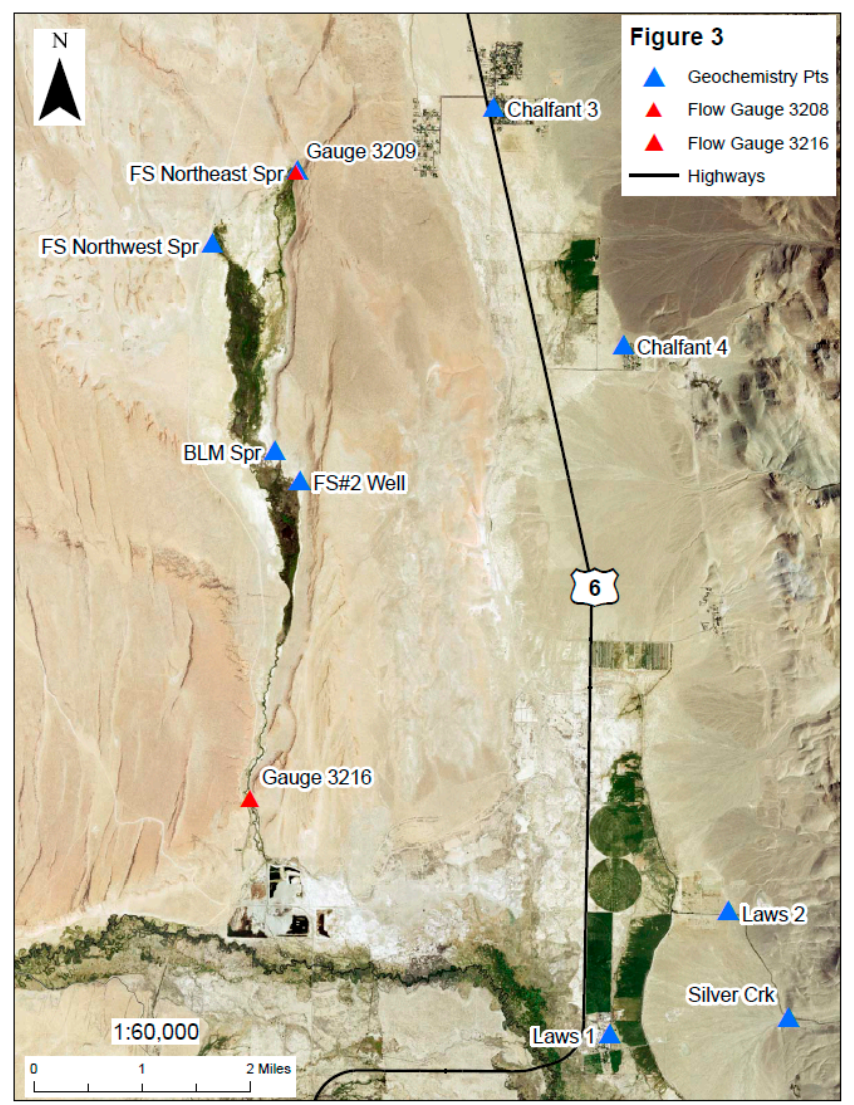

Figure 3. Flow measurement locations within Fish Slough valley.

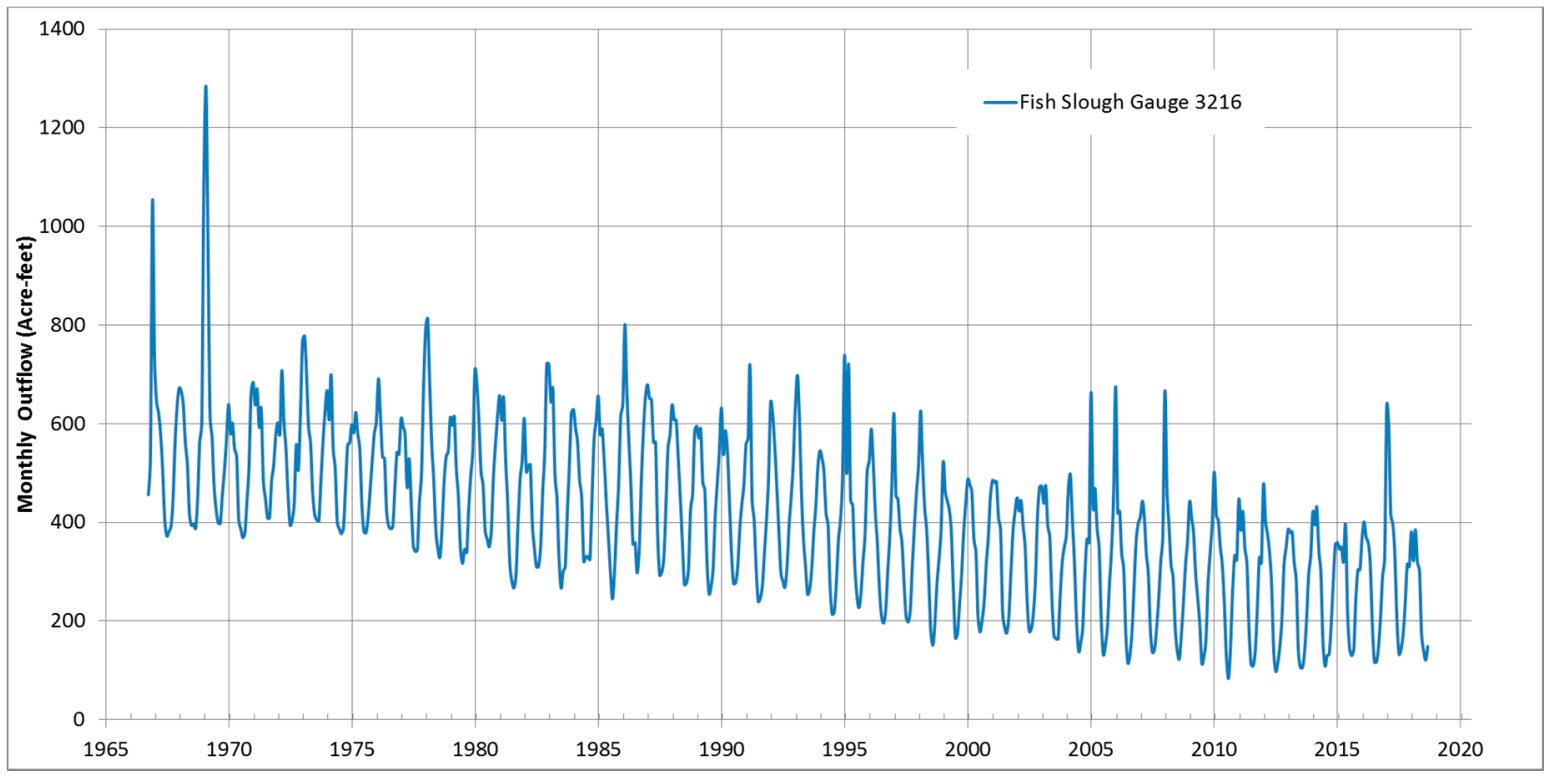

(a)

Figure 4. Cont. 


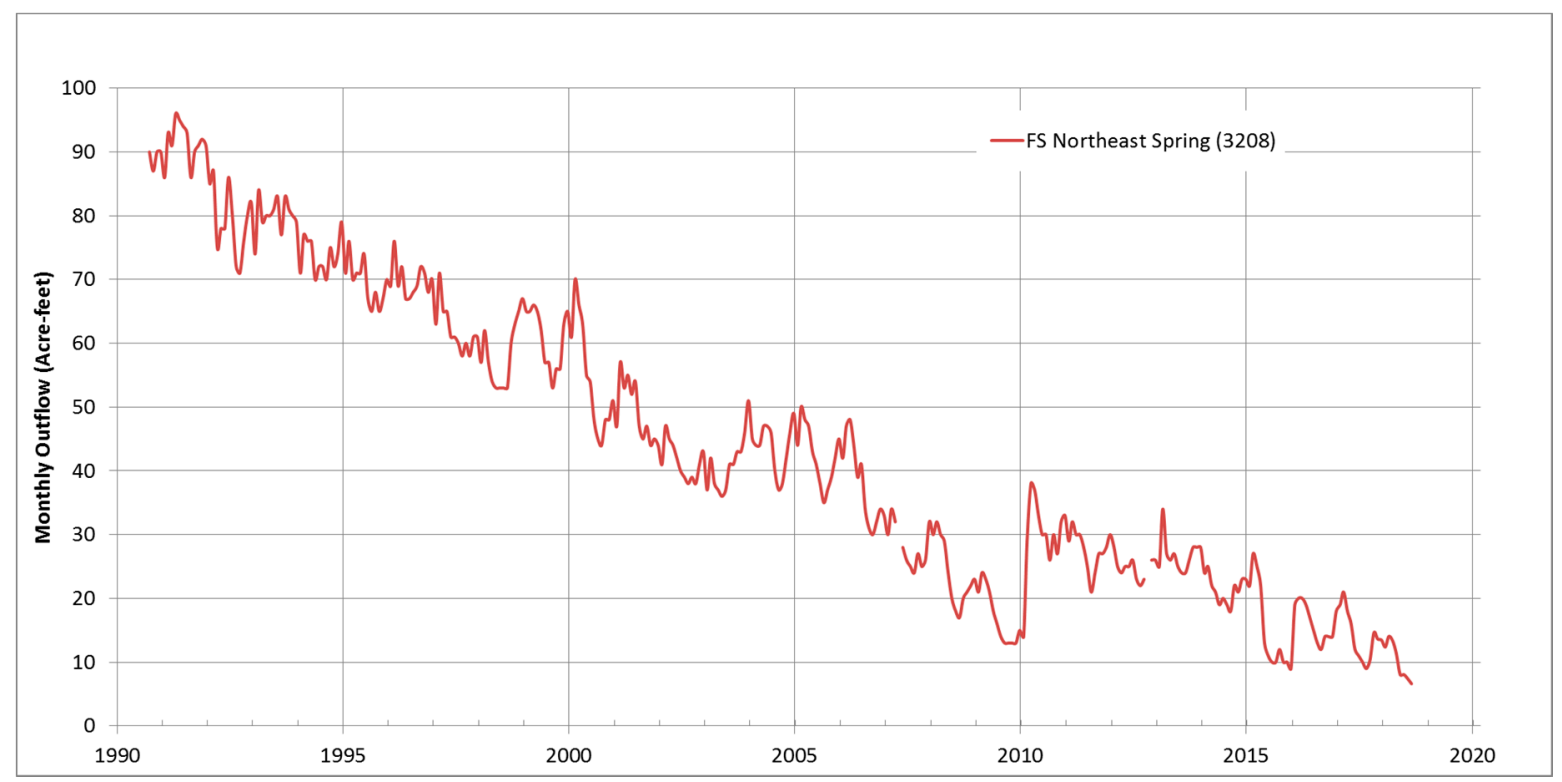

(b)

Figure 4. Hydrograph for (a) Gauge \#3216, "Fish Slough at LA Station" and (b) Gauge \#3208, "Fish Slough Below Pond 1".

\subsection{Geochemistry and Isotopic Composition}

Groundwater quality in Fish Slough generally contains moderate total dissolved solids contributed by appreciable levels of carbonate with lesser sulfate. To place this water quality in context, groundwater quality data gathered during this investigation were compiled with more regional data from U.S. Geological Survey [9], Jayko and Fatooh [10], and Mariner et.al. [21]. A piper diagram of Fish Slough spring waters and regional waters are provided in Figure 5.

\section{EXPLANATION \\ - Adobe Valley \\ $\times$ Benton \\ - Hammil \\ - Chalfant \\ + Laws}

$\star \quad$ Fish Slough (Northwest \& BLM) ${ }_{\times}^{\prime}$

$\star \quad$ Fish Slough (Northeast)

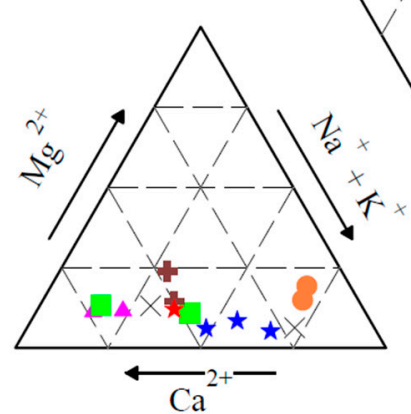

CATIONS
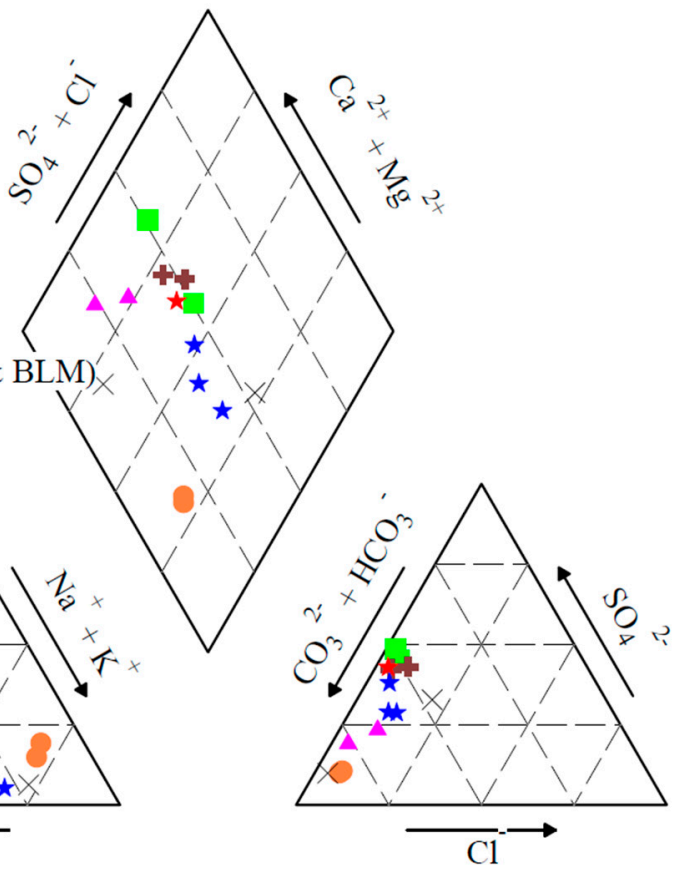

ANIONS

Figure 5. Piper diagram of Fish Slough spring waters compared to other regional water samples. Water chemistry data shown Table S1. 
As context for evaluating isotopic data, the $\delta^{18} \mathrm{O}$ and $\delta \mathrm{D}$ abundances in precipitation systematically vary with increasing latitude and elevation. Generally, this results in lower $\delta^{18} \mathrm{O}$ and $\delta \mathrm{D}$ isotope values at more northern latitudes, higher elevations, further distance inland, or rain-shadowed areas. The effect of these precipitation patterns on isotopic values combined with further fractionation caused by evaporation or interaction of groundwater with host minerals provides a potential means to derive recharge sources and flow paths of groundwater to springs in the Fish Slough area. This methodology has been used previously in the Basin and Range (e.g., Zdon, Davisson, and Love [14] in the Amargosa Basin of the southern Basin and Range geomorphic province) and is a standard methodology [22] to evaluate source areas for groundwater.

As part of this investigation, BLM Spring, Northwest Spring, Northeast Spring, and other springs in the area such as River Spring, Antelope Spring, Deer Springs, seeps near Black Lake, and cool springs near Benton Hot Springs were sampled and analyzed for stable isotope constituents and ${ }^{3} \mathrm{H}$. These data were compared with previous stabile isotopic data collected in the area $[4,9,10,18]$. A plot of the stable isotope results is provided in Figure 6.

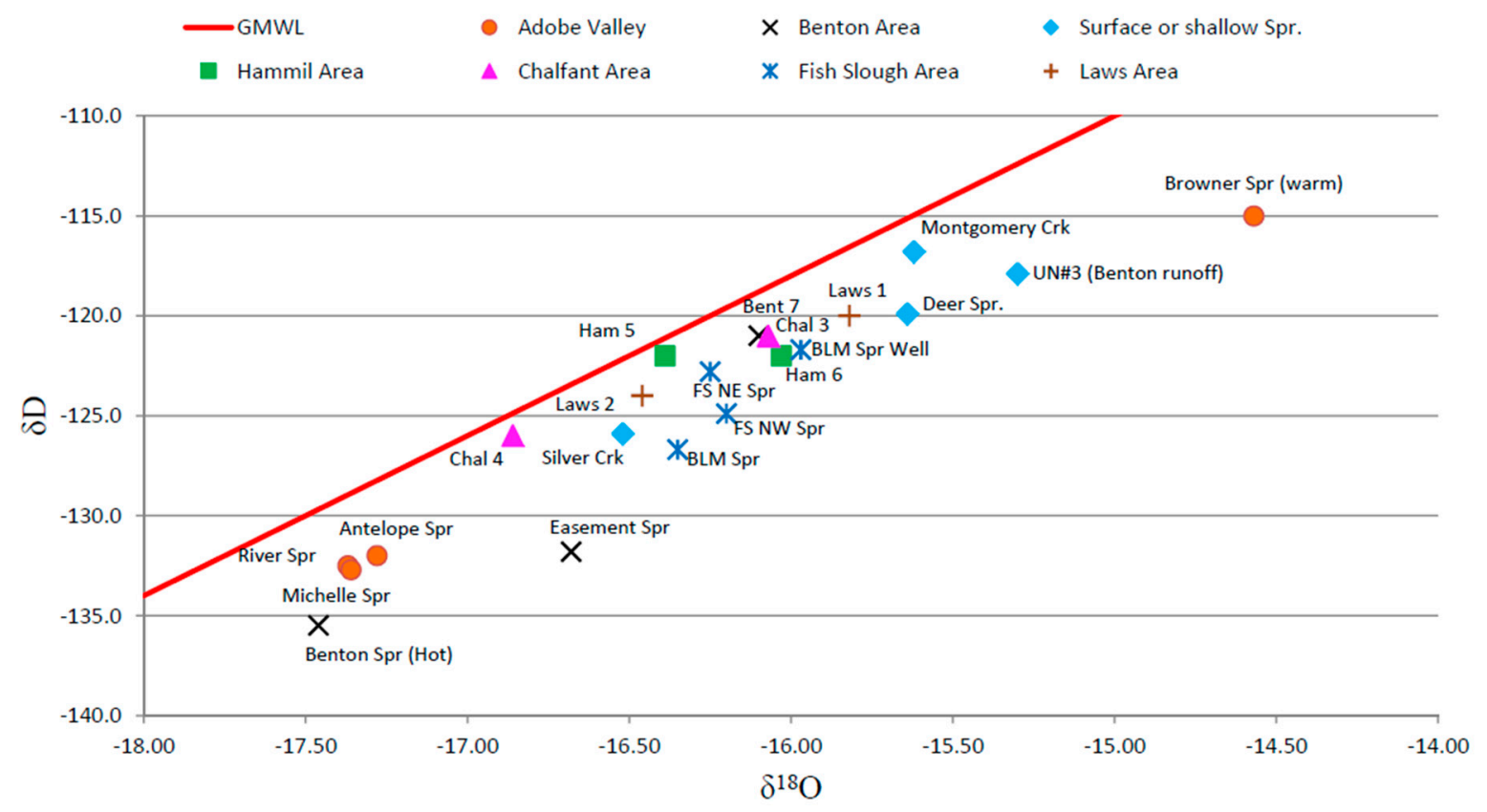

Figure 6. Stabile isotope characteristics of Fish Slough spring waters compared to other regional water samples. Isotope data table shown Table 1.

Thus, the character of waters in Fish Slough can be used to identify key potential source areas. With respect to the following water chemistry discussion, water types are referred to in a standard manner [23] based on the most common ions as expressed in milliequivalents per liter (meq/l). Therefore, water with the most common ions being sodium and sulfate would be termed a "sodium-sulfate" water (or Na-SO 4 type). This term for water type is not referring to sodium sulfate as a specific compound (such as $\mathrm{Na}_{2} \mathrm{SO}_{4}$ ). This terminology also assumes that those dominant ions constitute more than $50 \%$ of the cations or anions present. If for instance sodium consisted of $40 \%$ of the cations and calcium $30 \%$, then the water would be considered mixed, the ions would be named in order of dominance, and in this example the water would be a sodium-calcium-sulfate water [23].

\subsubsection{Adobe Valley Area}

The Adobe Valley groundwater basin is recharged principally from infiltration of rainfall and snowmelt runoff from the Glass Mountains and the surrounding Benton Range. Adobe Creek provides recharge to the northern end of the valley where it terminates, and Black Canyon Creek provides 
recharge to the southern portion of the basin [24]. Water features sampled in Adobe Valley are located on Figure 1 with data presented on Table 1.

The current study reconnoitered/sampled five locations across eight lateral miles in the Adobe Valley:

- $\quad$ River Spring (at two spring vents)

- Antelope Spring

- "Michelle Spring" (Black Lake vicinity)

- "Browner Spring" (Black Lake vicinity)

With the exception of Browner Spring (see below), spring water was found to be a sodium bicarbonate $\left(\mathrm{Na}-\mathrm{HCO}_{3}\right)$ type. Stable isotope analyses were conducted on all the springs for which surface water was present. As seen in their general chemistry, values of $\delta^{18} \mathrm{O}$ and $\delta \mathrm{D}$ for spring waters in Adobe Valley were also tightly clustered (approximately -17.3 and -132 , respectively). The exception was Browner Spring, a seep adjacent to Black Lake, that had $\delta^{18} \mathrm{O}$ and $\delta \mathrm{D}$ values of approximately -15 and below -120 , respectively. Additionally, Browner Spring had an anomalously elevated temperature as measured in the field. Additional sampling could be performed to further assess the nature and extent of this anomaly.

\subsubsection{Benton Hot Springs Area}

The Benton Hot Springs area has both cool and hot springs present (Table 1). Spring discharge in this area is of a Na- $\mathrm{HCO}_{3}$ type. Stable isotopic values for the hot springs were the most negative of all values identified in this investigation with $\delta^{18} \mathrm{O}$ and $\delta \mathrm{D}$ values of -17.46 and -135.5 , respectively. Elsewhere, a pair of cool springs (Easement Springs) located east of Benton Hot Springs at the base of the northwest slope of Blind Spring Hill yielded $\delta^{18} \mathrm{O}$ and $\delta \mathrm{D}$ values of approximately -16.6 and -135 , respectively.

\subsubsection{Additional Northern Areas}

Deer Spring, located south of the Benton Range and Banner Ridge, is a smaller local spring in Mesozoic-aged quartz monzonites and granodiorites as opposed to other springs in Cenozoic-aged volcanic terrain. Water sampled at this spring was of calcium bicarbonate $\left(\mathrm{Ca}-\mathrm{HCO}_{3}\right)$-type. In addition, a sample of surface runoff from snowmelt was collected in granitic/rhyolitic tuff terrain at the northern extent of the Benton Range above Benton Hot Springs (UN\#3 Benton Runoff). This sample had $\delta^{18} \mathrm{O}$ and $\delta \mathrm{D}$ values of -15.3 and -117.9 , respectively. Both of these areas had isotopic values similar to stream runoff in nearby Montgomery Creek located to the east at the foot of the White Mountains

\subsubsection{Tri-Valley Basin Fill}

The basin fill of the Tri-Valley area (Benton, Hammil, and Chalfant Valleys and including the Laws area of the northern Owens Valley) contains groundwater that is generally of $\mathrm{Ca}-\mathrm{HCO}_{3}$-type. During 2006, the USGS conducted groundwater sampling as part of the GAMA program. These results were incorporated into this analysis and $\delta^{18} \mathrm{O}$ and $\delta \mathrm{D}$ values ranged between -15.8 and -16.8 , and -120 to -126 , respectively. In addition to these analyses, the current study sampled surface water from Silver Creek (near Laws) and Montgomery Creek (near Benton).

\subsubsection{Fish Slough Springs}

A notable difference in discharge water chemistry was detected in the Fish Slough springs complex. BLM and Northwest Springs reflect $\mathrm{Na}-\mathrm{HCO}_{3}$-type waters while water from Northeast Spring is enriched in calcium. The Na- $\mathrm{HCO}_{3}$-type water of BLM and Northwest springs is similar to the water from Adobe Valley and Benton Hot Springs where recharge percolates through similar rhyolitic volcanic rocks. The water type for Northeast Spring is more consistent with groundwater from the Tri-Valley basin $\left(\mathrm{Ca}-\mathrm{HCO}_{3}\right.$-type water in an alluvial fill aquifer system) where calcium is 
the more prevalent cation. This heterogeneity is markedly different from the more laterally dispersed Adobe Valley Springs.

Field water quality parameters noted for BLM Spring were a temperature of 20.0 degrees Centigrade $\left({ }^{\circ} \mathrm{C}\right)$, or 68 degrees Fahrenheit $\left({ }^{\circ} \mathrm{F}\right)$, with a $\mathrm{pH}$ of 7.66 , and electrical conductivity of 436 microsiemens $(\mu \mathrm{S})$. At Northwest Spring, field parameters were a temperature of $20.3^{\circ} \mathrm{C}$, or 68.5 ${ }^{\circ} \mathrm{F}$, with a $\mathrm{pH}$ of 7.89 , and electrical conductivity of $356 \mu \mathrm{S}$. At Northeast Spring, field parameters were a temperature of $21.6^{\circ} \mathrm{C}$, or $70.9^{\circ} \mathrm{F}$, with a pH of 7.89 , and electrical conductivity of $384 \mu \mathrm{S}$.

Shallow groundwater temperatures will typically mimic the average annual ambient air temperature at that location. For the three principal Fish Slough springs, the water directly at the source location for each of the springs are approximately $13^{\circ} \mathrm{F}$ warmer than the average annual temperature. This indicates that the water at the springs has either been at significant depth below ground surface during its history, is in communication with thermal waters with a shallow heat source, or both. Subsurface temperatures are affected by climatic conditions to depths of about 100 feet below surface. As has been reported in Nevada (and is likely comparable at this location), below 100 feet temperatures normally increase $\sim 1$ degree $\mathrm{F}$ for every 55 feet of depth [25].

Tritium was identified in the water samples collected from Northeast Spring at a concentration of $0.76 \pm 0.25 \mathrm{TU}$, but was not detected in BLM Springs. Groundwater from the Tri-Valley area (from Benton to Laws) sampled for GAMA all contained 3H, but these USGS studies used specialized analytical techniques to obtain very low detection limits. Therefore, a nondetect for tritium in the current investigation does not necessarily indicate a nondetect would have been obtained using GAMA's more sensitive laboratory techniques. Nonetheless, the only samples with detectable $3 \mathrm{H}$ concentrations in the current investigation are from the local (shallow) Deer Springs and Fish Slough Northeast Springs. Water from Northeast Spring therefore appears to be of younger origin (post 1952) consistent with waters of the alluvial Tri-Valley groundwater basins. When combined with the results from the stable isotope analysis (below), the source for Northeast Spring appears to be substantially influenced by alluvial groundwater from the Tri-Valley area. Tritium was only sampled for key locations (Table 1) during the current investigation and additional sampling should be considered in the future for further data refinement.

As can be seen in the Piper Diagram (Figure 5) and the results of the stable isotope analysis (Figure 6), spring discharge at Fish Slough's BLM and Northwest Springs differs from the Northeast Spring. There is a notable trend toward increasing sodium content and decreasing $\delta \mathrm{D}$ values. Spring water from the Northwest and BLM springs appears either more evaporated (as illustrated by offset from the Global Meteoric Water Line) or having had additional water/rock interaction than Northeast Spring water.

Based on these results, it appears that a portion of the groundwater moving south through the TriValley groundwater basins, moves toward Fish Slough in southern Hammil Valley and is a source of Northeast Spring discharge. Below Northeast Spring in the Fish Slough system, the Tri-Valley basin fill-derived groundwater mixes with older, more sodic groundwater, diluting the ${ }^{3} \mathrm{H}$ concentrations present in the Tri-Valley area-derived groundwater.

\section{Discussion}

There has been a multidecade decline in discharge in the Fish Slough springs as measured both at Fish Slough Northeast springs (Gauge 3208) and totalized at the southern end of the springs (Gauge 3216). Based on the analysis and integration of the new and historic data collected combined with the geologic and hydrogeologic framework of the region, the discharge amount and sources of the springs evaluated appear to be as follows.

1. Northeast Spring is from a regional water source, deriving part of its water from the alluvial Tri-Valley groundwater system. This conclusion is based on 
a. general chemistry similarity to the $\mathrm{Ca}-\mathrm{HCO}_{3}$ water type identified in the Tri-Valley area alluvial basins which differs significantly from the $\mathrm{Na}-\mathrm{HCO}_{3}$ waters identified in the Benton Hot Springs and the Adobe Valley springs;

b. stable isotope ratios are similar to those identified in the Tri-Valley area and separated from BLM and Northwest Springs; and

c. the presence of $3 \mathrm{H}$ indicating that the spring water has a composite post-1950 age similar to that identified in the Tri-Valley groundwater system.

2. Northwest and BLM Springs are regionally derived and are a possible mixture of more sodic sources to the north (Adobe Valley and Benton Hot Springs area) and northwest (Volcanic Tablelands), mixing with Fish Slough Northeast Spring/Tri-Valley water. This conclusion is based on

a. general chemistry similarity to Tri-Valley water but with increasing sodium content with increased distance from Northeast Spring and trending toward the more volcanically-derived chemistry of the Adobe Valley waters;

b. stable isotope ratios mid-range between Tri-Valley basin-fill groundwater and groundwater in the Adobe Valley/Benton Hot Springs area; and

c. absence of $3 \mathrm{H}$, potentially indicative of a longer flow path or dilution of tritium-bearing water from Northeast Springs to nondetectable values from non-3H-bearing groundwater from the northwest.

3. Source water mixing combines two key source areas that feed the Fish Slough springs. These waters mix downgradient from Northeast Spring. In this area, transitional geochemical conditions and the diluting out of ${ }^{3} \mathrm{H}$ that is observed at Northeast Spring (and absent from BLM and Northwest Spring) occurs.

The use of a more geographically wide-ranging investigation than previous investigations resulted in a more comprehensive and clearer understanding of the source of Fish Slough. These results have identified additional source areas contributing to spring flow in the Fish Slough area, including connections to the regional aquifer systems. The connections to the regional aquifer systems explain how regional water withdrawals in the area have resulted in the decline of spring flow in the Fish Slough area over time. This improved conceptual model of the hydrogeologic sources to Fish Slough springs requires further assessment in order to better understand the dynamics and parameters of the contribution from each water source to each spring, including, but are not limited to

- regularly resampling of springs to evaluate seasonal changes in geochemical characteristics in Fish Slough spring geochemistry;

- regular monitoring and maintenance of flow gauges and channels is recommended to collect accurate data and minimize erroneous measurements;

- radiocarbon analysis of spring discharge to further assess rates of groundwater movement;

- additional surface water, spring water, or groundwater sampling from existing wells in the vicinity of Fish Slough, to further refine the chemical characteristics and pathways of regional waters;

- additional hydraulic characterization of the system including installation of monitoring wells (potentially screened both in and below the Bishop Tuff) in the Fish Slough and the Hammil/Chalfant Valley area to monitor groundwater levels in conjunction with spring flow monitoring; and

- development of a numerical model of the Tri-Valley and Fish Slough areas as a water management tool for the Tri-Valley/northern Owens Valley.

Future groundwater development and management in the region should be cognizant of the potential hydraulic connection between the basin-fill aquifer in the southern Hammil-northern Chalfant valleys and Fish Slough. 
Supplementary Materials: The following are available online at http://www.mdpi.com/2306-5338/6/1/26/s1, Table S1: Geochemistry data from sample locations in Figure 1.

Author Contributions: Conceptualization, A.Z.; Methodology, A.Z..; Formal Analysis, A.Z.., K.R., N.B., S.P., and A.H.L.; Investigation, A.Z., K.R., N.B., and S.P.; Resources, A.Z..; Writing-Original Draft Preparation, A.Z..; Writing-Review and Editing, A.Z.., K.R., N.B., S.P., and A.H.L.; Visualization, A.Z., K.R., and N.B..; Supervision, A.Z.; Project Administration, A.Z.; Funding Acquisition, A.Z.

Funding: The authors would like to thank the U.S. Bureau of Land Management (BLM) for providing the financial support for the completion of this work.

Acknowledgments: The authors would also like to acknowledge the Transition Habitat Conservancy and Eastern Sierra Land Trust for their assistance with this project.

Conflicts of Interest: The authors declare no conflicts of interest. The funders had no role in the design of the study; in the collection, analyses, or interpretation of data; in the writing of the manuscript, or in the decision to publish the results.

\section{References}

1. Kresic, N. Types and Classification of Springs. In Groundwater Hydrology of Springs: Engineering, Theory, Management, and Sustainability; Butterworth-Heinemann (Elsevier): Burlington, NJ, USA, 2010; pp. 31-86.

2. Knopf, A.; Kirk, E. A Geologic Reconnaissance of the Inyo Range and the Eastern Slope of the Southern Sierra Nevada, California; U.S. Geological Survey Professional Paper 110; U.S. Geological Survey: Reston, VA, USA, 1918; 130p.

3. Bateman, P. Geology and Tungsten Mineralization of the Bishop District, California; U.S. Geological Survey Professional Paper 470; U.S. Geological Survey: Reston, VA, USA, 1965.

4. California Department of Water Resources. Fish Slough Dam and Reservoir: Feasibility Investigation; California Department of Water Resources Bulletin No. 126; California Department of Water Resources: Sacramento, CA, USA, 1964; 62p.

5. University of California. Biotic Inventory and Ecosystem Characterization for Fish Slough, Inyo and Mono Counties, California; Grant Report Prepared for State of California Resources Agency, Department of Fish and Game: Sacramento, CA, USA, 15 June 1991.

6. Danskin, W.R. Evaluation of the Hydrologic System and Selected Water-Management Alternatives in the Owens Valley, California; U.S. Geological Survey Water-Supply Paper 2370-H; U.S. Geological Survey: Reston, VA, USA, 1998; 175p.

7. Hollett, K.J.; Danskin, W.R.; McCaffrey, W.F.; Walti, C.L. Geology and Water Resources of Owens Valley, California; U.S. Geological Survey Water-Supply Paper 2370-B; U.S. Geological Survey: Reston, VA, USA, 1991; pp. B1-B77.

8. Chapman, J. Stable Isotope Investigation of the Source Water for the Fish Slough Springs, California; Letter Report: Division of Hydrologic Sciences; Desert Research Institute: Reno, NV, USA, 2002; 9p.

9. United States Geological Survey. National Water Information Service (NWIS). 2018. Available online: https:/ / maps.waterdata.usgs.gov/mapper/index.html (accessed on 30 June 2018).

10. Jayko, A.S. Fish Slough, a Geologic and Hydrologic Summary, Inyo and Mono Counties, California; U.S. Geological Survey Administrative Report Prepared for BLM Bishop Field Office; U.S. Geological Survey: Reston, VA, USA, 2010; 30p.

11. California Department of Fish and Wildlife. Fish Slough Vegetation Map; California Department of Fish and Wildlife: Sacramento, CA, USA, 2014.

12. Andy Zdon \& Associates, Inc. Mojave Desert Springs and Waterholes: Results of the 2015-2016 Mojave Desert Spring Survey, Inyo, Kern, San Bernardino and Los Angeles Counties, California; Andy Zdon \& Associates, Inc.: Lafayette, CA, USA, 2016.

13. Zdon, A.; Davisson, M.L.; Love, A.H. Testing the Established Hydrogeologic Model of Source Water to the Amargosa River Basin, Inyo and San Bernardino Counties, California. Environ. Forensics 2015, 16, 334-355. [CrossRef]

14. Zdon, A.; Davisson, M.L.; Love, A.H. Understanding the source of water for selected springs within Mojave Trails National Monument, California. Environ. Forensics 2018, 19, 99-111. [CrossRef] 
15. Hildenbrand, T.G.; Briesacher, A.; Flanagan, G.; Hinze, W.J.; Hittelman, A.M.; Keller, G.R.; Kucks, R.P.; Plouff, D.; Roest, W.; Seeley, J.; et al. USGS Open File Report 02-463 “Rationale and Operational Plan to Upgrade the U.S. Gravity Database". 2002. Available online: https://research.utep.edu/default.aspx?tabid= 37229 (accessed on 20 February 2016).

16. Pakiser, L.C.; Kane, M.F.; Jackson, W.H. Structural Geology and Volcanism of Owens Valley Region, California-A Geophysical Study; USGS Professional Paper 438; USGS: Reston, VA, USA, 1964.

17. California Geological Survey. California Geomorphic Provinces. California Geological Survey Note 36; California Geological Survey: Sacramento, CA, USA, 2002; $4 \mathrm{p}$.

18. Calclim. California Climate Data Network. 2018. Available online: https://calclim.dri.edu/ (accessed on 30 June 2018).

19. Los Angeles Department of Water and Power. Totals and Means Report; Los Angeles Department of Water and Power: Los Angeles, CA, USA, 2018.

20. Parmenter, S.; California Department of Fish and Wildlife. Personal communications, 2018.

21. Mariner, R.H.; Presser, T.S.; Evans, W.C. Geochemistry of Active Geothermal Systems in the Northern Basin and Range Province; Geothermal Resources Council Special Report No. 13; Geothermal Resources Council: Olympia, WA, USA, 1983.

22. Kendall, C.; McDonnell, J.J. Isotope Tracers in Catchment Hydrology; Elsevier: Amsterdam, The Netherlands, 1998; 839p.

23. Hem, J.D. Study and Interpretation of the Chemical Characteristics of Natural Water; U.S. Geological Survey Water-Supply Paper 2254; U.S. Geological Survey: Reston, VA, USA, 1985; 263p.

24. California Department of Water Resources. Adobe Lake Valley Groundwater Basin, in California's Groundwater; California Department of Water Resources Bulletin 118; California Department of Water Resources: Sacramento, CA, USA, 2004.

25. Garside, L.J.; Schilling, J.H. Thermal Waters of Nevada; Nevada Bureau of Mines and Geology Bulletin 91; Nevada Bureau of Mines and Geology: Reno, NV, USA, 1979; 163p.

(C) 2019 by the authors. Licensee MDPI, Basel, Switzerland. This article is an open access article distributed under the terms and conditions of the Creative Commons Attribution (CC BY) license (http:/ / creativecommons.org/licenses/by /4.0/). 